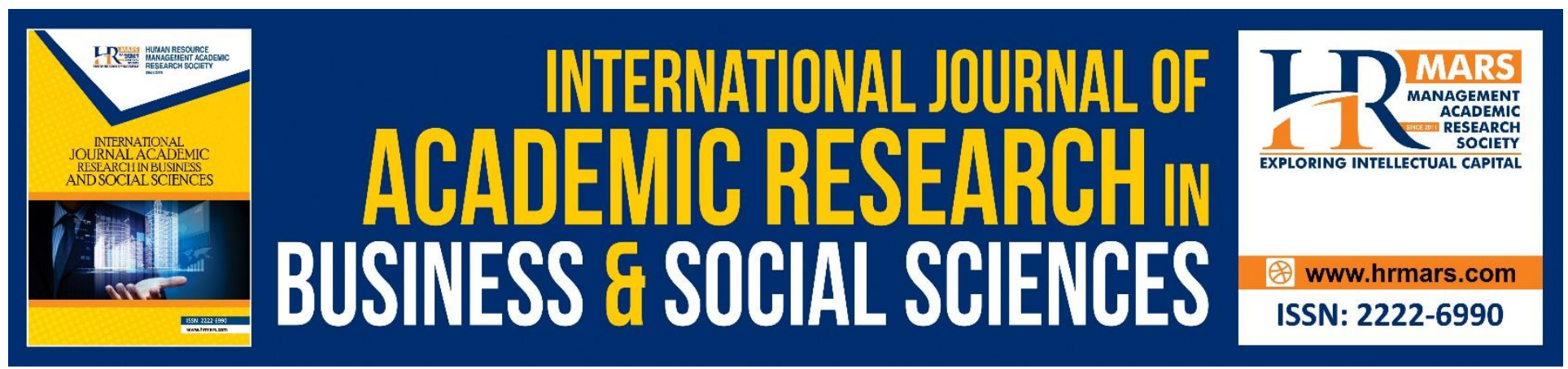

\title{
An Examination of Organizational Age Effect on Debt to Equity Ratio of Firms at the Nigeria Stock Exchange Market
}

\author{
Ugwu, Kevin Okoh \\ Obasuyi, George D \\ Mbah, Chris Chukwuemeka
}

To Link this Article: http://dx.doi.org/10.6007/IJARBSS/v9-i5/5904

DOI: $10.6007 /$ IJARBSS/v9-i5/5904

Received: 19 March 2019, Revised: 08 April 2019, Accepted: 27 April 2019

Published Online: 24 May 2019

In-Text Citation: (Ugwu, Obasuyi, \& Mbah, 2019)

To Cite this Article: Ugwu, K. O., Obasuyi, G. D., \& Mbah, C. C. (2019). An Examination of Organizational Age Effect on Debt to Equity Ratio of Firms at the Nigeria Stock Exchange Market. International Journal of Academic Research Business and Social Sciences, 9(5), 542-554.

\section{Copyright: (C) 2019 The Author(s)}

Published by Human Resource Management Academic Research Society (www.hrmars.com)

This article is published under the Creative Commons Attribution (CC BY 4.0) license. Anyone may reproduce, distribute, translate and create derivative works of this article (for both commercial and non-commercial purposes), subject to full attribution to the original publication and authors. The full terms of this license may be seen

at: http://creativecommons.org/licences/by/4.0/legalcode

Vol. 9, No. 5, 2019, Pg. 542 - 554

Full Terms \& Conditions of access and use can be found at http://hrmars.com/index.php/pages/detail/publication-ethics 


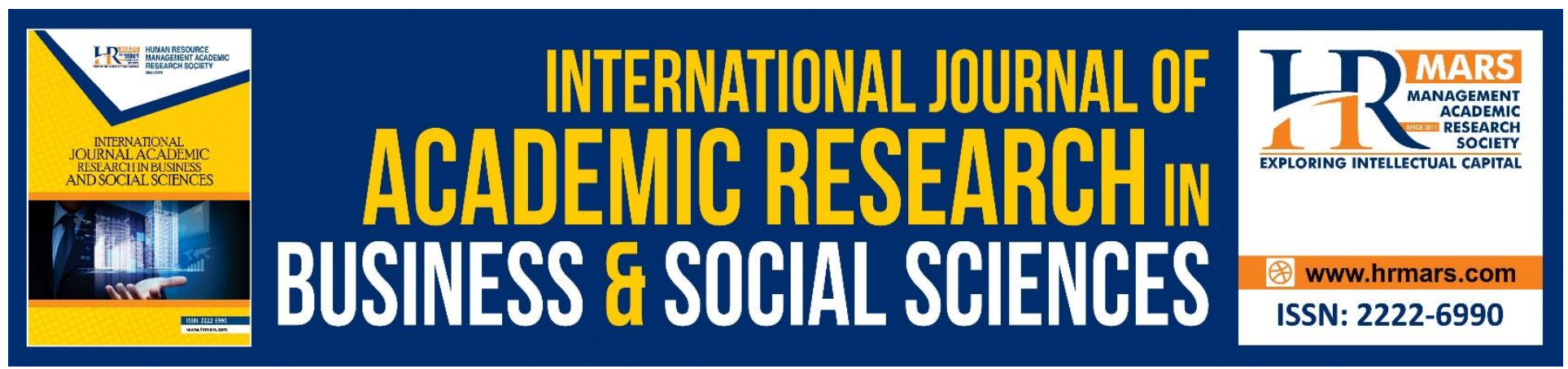

\title{
An Examination of Organizational Age Effect on Debt to Equity Ratio of Firms at the Nigeria Stock Exchange Market
}

\author{
Ugwu, Kevin Okoh, Ph.D, Obasuyi, George D. \\ Department of Accountancy, Faculty of Management Science, Enugu State University of Science and \\ Technology (ESUT), Enugu State, Nigeria. \\ Mbah, Chris Chukwuemeka (Ph.D) \\ Department of Marketing, Faculty of Management Sciences, Enugu State University of Science and \\ Technology \\ Email: kelvinugwu@ymail.com
}

\begin{abstract}
The paper seeks to examine organizational age effect on debt to equity ratio in Nigeria. The main objective of the study was to examine organizational age effect on debt to equity ratio. The relevant literature was reviewed for the purposes of this study. This study adopts the ex-post facto design. The paper uses secondary data only extracted from the Annual Reports and Accounts of 16 sampled firms out of the insurance companies in Nigeria. The target population of this study is the thirty-two (32) quoted insurance firms on the Nigerian Stock Exchange (NSE) and random sampling technique was used. Multiple regressions were used to analyse data and the hypotheses was tested at 5\% significant level using Statistical Package for Social Sciences (SPSS). It was found that Organizational age does not have significant effect on Debt to Equity Ratio ( $p$ value $=0.737$ ). The study recommended that managers should consider the organizational age effect on debt to equity ratio.
\end{abstract}

Keyword: Organizational Age, Equity Ratio, Pecking-Order

\section{Introduction}

One of the most repeatedly discussed subjects in financial management is that of organizations' capital structure. Akinyomi and Olagunju (2013), revealed that a company's capital structure refers to how a company finances its operations whether through shareholders equity fund or debt or a combination of both. Capital structure is made up of equity (shareholders' fund) and debt (liabilities) and there are external and internal factors that affect the capital structure of firms. The external factors, which are outside the control of the firms, can be classified into political/legal, social, 
economic and technological, while the internal factors are within the control of the firms and include the determinants of capital structure i.e. size, growth, profitability, tangibility and age.

Age is the age of the firm arrived at by finding the difference between the date of this study and the firm's incorporation date. In Nigeria, companies do not seem to have lived up to expectation of achieving optimum capital structure. If this is not achieved, it is at the peril of both the providers of capital and the firm itself. Hence, many developing countries have experienced financial problems requiring major reforms to address weak supervision of insurance firms and inadequate capital. In addition to deposit insurance (implicit or explicit), official capital structure regulations play a crucial role in aligning the incentives of owners of firms with clients. However, it is not altogether clear whether the imposition of capital requirements actually reduces risk-taking incentives. Higher capital requirements may induce clients to shift to capital markets and in the process impair capital allocation, while Gorton and Winton (1995) show that raising capital requirements can increase the cost of capital. Thus, theory provides conflicting predictions on whether capital requirements curtail or promote firms' performance.

This study attempts to determine organizational age effect on debt to equity ratio in Nigeria. The study aims at determining whether the independent or explanatory variable (organizational age), statistically and significantly influence the explained or dependent variable (Debt to Equity Ratio) and to identify organizational age effect on debt to equity ratio in Nigeria.

\section{Purpose of the Study}

To examine the effect of organizational age on debt to equity ratio

\section{Review of Related Literature}

\section{Equity}

Equity enables the firm to obtain funds without incurring debt. This means that the fund obtained through equity do not have to be repaid at a particular time. The investors purchase shares in the firm hope to reclaim their investment out of future profits. The shareholders have the privilege to share in the profits of the firm in the form of dividends or future capital gains. However, if the firm suffers a loss, the shareholders have limited liability, which means that the only loss they face is the amount that they had invested in the firm.

There are two kinds of equity: internal equity and external equity (Myers, 1984). Internal equity refers to the retained earnings of a firm which forms part of the firm's distributable reserves. When distributable profit is determined in the income statement, the firm has to decide what proportion of that profit will be paid out as dividends to the ordinary shareholders. The remaining amount represents the retained earnings and this amount will be carried over to the firm's distributable reserves in the balance sheet.

The retained earnings therefore represent the amount that is reinvested back into the firm. External equity refers to outside capital which is obtained through the issuing of new shares. It generally consists of ordinary share capital and preference share capital. A firm has to raise external equity when its internal equity (retained earnings) is not sufficient for the required investment opportunity. When a firm raises too much capital through equity issues, it could be interpreted as a signal to the market that it does not have sufficient reserves or cash flows, and this could result in the 
undervaluation of the firm's shares. When investments are financed with external equity, the share prices of firms sometimes fall. Therefore, it is better to build up reserves so that a higher proportion of capital needs can be supplied from internal sources (Modugu, 2013).

\section{Organizational Age}

Shehu (2011) opines that age of the firm is a standard measure of reputation in capital structure models. As a firm continues longer in business, it establishes itself as an ongoing business concern and therefore increases its capacity to take on more debt; hence age is expected to be positively related to debt. Before granting a loan, banks tend to evaluate the creditworthiness of entrepreneurs as these are generally believed to pin high hopes on very risky projects promising high profitability rates. In particular, when it comes to highly indebted companies, they are essentially gambling with their creditors' money. If the investment is profitable, shareholders will collect a significant share of the earnings, but if the project fails, then the creditors have to bear the consequences (Myers, 1977). To overcome problems associated with the evaluation of creditworthiness, Diamond (1984) suggests the use of firm reputation. He takes reputation to mean the good name a firm has built up over the years; the name is recognized by the market,

\section{The Pecking-Order Theory}

Myers (1984) and Myers and Majluf (1984) suggest that capital structure choice is driven by the magnitude of information asymmetry present between the firm and outside investors. The more severe the information asymmetry, the more risk the outside investors are facing and hence the more discount they demand on the price of issued securities. Consequently, firms will prefer financing through internal funds and if they do need to raise outside capital, they will firstly issue risk-free debt then followed by low-risk debt. Equity is only issued as a last resort. As stated in Myers (1984), the static trade-off theory assumes that firms set an optimal debt ratio and they move gradually towards it. The theory proposes that the optimal debt ratio is set by balancing the trade-off between the benefit and cost of debt. The benefit of debt arises from the tax deductibility of interest payments on debt and the cost of debt comes in the form of higher probability of bankruptcy and the loss suffered in the event of bankruptcy.

The pecking order theory is based on the assertion that firms use debt only when retained earnings are insufficient and raise external equity capital only as a last resort. More recent models of capital structure choice include 'windows of opportunity' and 'managerial optimism' (Heaton, 2002). Baker and Wurgler (2002) suggest that managers could minimize the cost of capital by timing the market (issuing equity when share prices increase) implying that market conditions influence the pecking order. However, Hovakimian (2006) shows that the timing of equity issuance does not have any significant long-lasting impact on capital structure. In a quest for the factors that managers consider in deciding the financing mix of a firm, many studies have examined the role of several firm-specific factors. In a review article, Harris and Raviv (1991) report that leverage is positively related to nondebt tax shields, firm size, asset tangibility, and investment opportunities, while it is inversely related to bankruptcy risk, research and development expenditure, advertising expenditure, and firm's uniqueness. 


\section{Previous Studies on Effect of Age on Debt to Equity Ratio}

Chandrasekharan (2012) investigated the potential determinants of capital structure among listed Nigerian firms for a period of five years from 2007 to 2011 using panel multiple regression and discovered that Age is a strong determinant of leverage in the Nigerian firms.

Vitor and Badu (2012) studied Capital Structure and Performance of Listed Banks in Ghana from 2000 to 2010 using Panel Regression and found that Age of the firm is negatively insignificant to Leverage. Chechet, Garba and Odudu (2013) examined the determinants of Capital Structure in the Nigerian Chemical and Paints Sector from 2005 to 2009 using OLS regression method of data analysis and discovered that Age has insignificant impact on Leverage.

Akorsu (2014) tested the pecking order and signaling theories for 26 financial Institutions in Ghana from 2005 to 2012 employing the panel data methodology in the model estimation. The results showed that age is positively correlated with Leverage.

Bassey, Arene and Okpukpara (2014) studied the determinants of Capital Structure of twenty eight (28) agro-allied firms, which have been listed on the Nigeria Stock Exchange (NSE) from 2005 to 2010 using Ordinary Least Squares (OLS). The results showed that Firm age is positively related to long term debt ratio.

Shala, Ahmeti, Berisha and Perjuci (2014) investigated the factors that determine the capital structure among insurance companies in Kosovo, based on data retrieved from 11 insurance companies during the period 2009-2012 using the Random Effect (RE) model. The result showed that Age has positive relationship with the debt ratio and also has significant effect on it.

Mutairi and Naser (2015) studied the Determinants of Capital Structure of Banking Sector in 47 Gulf Cooperation Council (GCC) Commercial Banks from 2001 to 2010 employing Panel Data Analysis. It was found that there is negative relationship between Age and Leverage.

Oke and Obalade (2015) investigated the determinants of capital structure in Nigerian oil industry for the period 2005 to 2012 employing Pooled OLS, Fixed and Random Effect Model for analytical purpose. It was found that Age is significant in determining the capital structure of Nigerian oil firms. Guruswamy and Marew (2016) examined the determinants of capital structure of selected insurance companies in Ethiopia using multiple regression analysis. It was discovered that Age is one of the most important determinant factors of capital structure.

\section{Methodology}

This study adopts the ex-post facto i.e. after the fact or event. The paper uses secondary data only extracted from the Annual Reports and Accounts of 16 sampled firms out of the insurance companies in Nigeria representing $50 \%$ of the population. Random sampling technique is employed to select the firms so as to ensure that all the firms have equal chance of representation and also depending on availability of data. Multiple regression is used as a tool of analysis for the study covering a period of 11 years (2006-2016) using Statistical Package for Social Science (SPSS).

\section{Area of Study}

The focus of this study is on organizational age effect on debt to equity ratio in Nigeria 
INTERNATIONAL JOURNAL OF ACADEMIC RESEARCH IN BUSINESS AND SOCIAL SCIENCES

Vol. 9, No. 5, May, 2019, E-ISSN: 2222-6990 (C) 2019 HRMARS

\section{Sources of Data}

Secondary data are extracted from the annual reports and accounts of the sixteen (16) sampled firms based on availability of data.

\section{Population of the study}

The population of this study is the thirty-two (32) quoted insurance firms on the Nigerian Stock Exchange (NSE) as at $31^{\text {st }}$ December, 2016. (Otaru, 2017).

\section{Sample Size}

Random sampling is used to select the insurance firms from the population of thirty-two (32) by arranging the population in groups of twos and one firm selected from each group, thereby giving a fair chance of representation of the population and based on data availability.

\section{Method of Data Collection}

The data collected from the annual reports of the sampled insurance firms are presented in tabular forms namely summary of descriptive statistics, summary of coefficient of correlation, summary of regression results, model summary and Analysis of Variance (ANOVA). Multiple regression is used to analyse data and test the hypotheses at 5\% significant level i.e. 0.05 using Statistical Package for Social Scientists (SPSS).

\section{Data Analysis and Presentation of Results}

Table 2: Summary of Regression result

Variable Coefficient Standard Error t. test Probability

\begin{tabular}{|c|c|c|c|c|c|c|}
\hline & B & Std Error & $\mathrm{t}$ & & Tolerance & VIF \\
\hline CONSTAN & -11.861 & 6.658 & -1.781 & 0.079 & & \\
\hline SIZE & 1.531 & 0.698 & 2.193 & 0.031 & 0.940 & 1.054 \\
\hline GROWTH & -0.102 & 0.131 & -0.780 & 0.438 & 0.967 & 1.035 \\
\hline PROF & -9.746 & 3.444 & -2.830 & 0.006 & 0.921 & 1.086 \\
\hline TANG & 0.090 & 1.696 & 0.053 & 0.958 & 0.881 & 1.135 \\
\hline AGE & -0.008 & 0.024 & -0.337 & 0.737 & 0.946 & 1.057 \\
\hline
\end{tabular}

Table 3.

Model Summary

\begin{tabular}{|l|r|r|r|r|r|}
\hline Model & $\mathrm{R}$ & R Square & $\begin{array}{c}\text { Adjusted R } \\
\text { Square }\end{array}$ & $\begin{array}{c}\text { Std. Error of the } \\
\text { Estimate }\end{array}$ & Durbin-Watson \\
\hline 1 & $.399^{\mathrm{a}}$ & .159 & .106 & 2.94952 & 2.301 \\
\hline
\end{tabular}

Source: SPSS computation

Table 4.

\begin{tabular}{|c|c|c|c|c|c|c|}
\hline \multicolumn{2}{|c|}{ Model } & Sum of Squares & Df & Mean Square & $\mathrm{F}$ & Sig. \\
\hline \multirow[t]{3}{*}{1} & Regression & 129.943 & 5 & \multirow{3}{*}{$\begin{array}{r}25.999 \\
8.700\end{array}$} & \multirow[t]{3}{*}{2.987} & \multirow[t]{3}{*}{0.016} \\
\hline & Residual & 687.272 & 79 & & & \\
\hline & Total & 817.215 & 84 & & & \\
\hline
\end{tabular}


Source: SPSS computation

R-square 0.159

Adjusted R-square 0.106

Durbin-Watson 2.301

F-statistic 2.987

Prob (F-statistic) 0.016

From the summary of the estimated regression model in table 3 ,

D/ER = -11.861+1.531 SIZE-0.102 GROWTH -9.746 PROF+ 0.090-0.008 AGE

From table 2, the age variable has $p$ value of 0.737

DECISION RULE: At $5 \%$ significant level, if the $p$ value of the age variable is less than 0.05 (i.e. $p<0.05$ ), it is significant and we reject the null hypothesis, while if it is greater than 0.05 (i.e. p>0.05), it is insignificant and we fail to reject the null hypothesis.

Therefore the age variable with $p$ value of 0.737 is insignificant at the 0.05 level, thus we fail to reject the null hypothesis and conclude that age does not have significant effect on Debt to Equity Ratio.

\section{Discussion of Findings}

The age of the firm was found to be negatively correlated with leverage which disagrees with the findings of Diamond (1984) who takes reputation to mean the good name a firm has built up over the years; the name is recognized by the market, which has observed the firm's ability to meet its obligations in a timely manner, but in agreement with the findings of Shehu (2011). It is in agreement with the pecking Order Theory but in disagreement with the Trade-Off theory.

\section{Summary of Findings}

Organizational age does not have significant effect on Debt to Equity Ratio.

\section{Recommendation}

1. The impact of age on capital structure is imperative in debt financing decisions. Age has an insignificant negative effect on Debt to Equity Ratio. Therefore as firms continue longer in business, debt does not increase thereby minimising the possibility of liquidation and bankruptcy costs. So older firms should be encouraged to continue in business and minimise debt.

\section{References}

Adair, P. and Adaskou, M. (2015). Trade-Off Theory Vs Pecking-Order Theory and the Determinantsnal of Corporate Leverage: Evidence from a Panel Data Analysis upon French SMEs (2002-2010). Cogent Economics and Finance, 3(1).

Adaramola, A. O. and Olarewaju, O. M. (2015). Determinants of capital structure in Nigerian quoted composite insurance companies. Global Journal of Management and Business Research: C Finance, 15(10).

Adeyemi, S. B. and Oboh, C. S. (2011). Perceived Relationship between Corporate Capital Structure and Firm Value in Nigeria. International Journal of Business and Social Science, 2(19).

Akhtar, N., Bano, M. and Bano, S. (2016). Capital Structure Impact on Banking Sector 
INTERNATIONAL JOURNAL OF ACADEMIC RESEARCH IN BUSINESS AND SOCIAL SCIENCES Vol. 9, No. 5, May, 2019, E-ISSN: 2222-6990 ㄷ 2019 HRMARS

Performance in Pakistan. International Review on Management and Business Research, 5(2): 519-535.

Akingunola, R. and Oyetayo, O. (2012). Determinant of Financial Structure Decision in Small and Medium Enterprises: A pilot Study of Selected Registered Companies in Nigeria. Journal of Economics and Finance, 3(1): 1-8.

Akinlo, O. (2011). The determinants of capital structure: evidence from Nigeria panel data. African Economy and Business Review, 9(1): 1-16

Akinyomi, O. J and Olagunju, A. (2013). Determinants of capital structure in Nigeria. International Journal of Innovation and Applied Studies, 3(4): 999-1005.

Akorsu, P. K. (2014). Testing the Pecking Order and Signalling Theories for Financial Institutions in Ghana. Research Journal of Finance and Accounting, 5(16).

Aremu, M. A., Ekpo, S. L., Mustapha, A. S. and Adedoyin, S. I. (2013). Determinants of capital structure in Nigerian banking sector. International Journal of Academic Research in Economics and Management, 2, 27-43.

Bakara, L. and Oladipupo, M. (2013). Insurance Industry: A Review. Journal of Pan African Capital Research, 1, 1-2.

Baker, M. and Wurgler, J. (2002). Market Timing and Capital Structure. The Journal of Finance, 57(1): 1-32.

Banerjee, S., Heshmati, A. and Wihlborg, C. (2000). The dynamics of capital structure. SSE/EFI Working Paper Series in Economics and Finance, 333, 1-20.

Barclay, M. J., Smith, C. W. and Watts, R. L. (1995). The determinants of corporate leverage and dividend policies. Journal of Applied Corporate Finance, 7, 4-19.

Barclay, M. J. and Smit, C. W. (2005). The Capital Structure Puzzle: The Evidence Revisited. Journal of Applied Corporate Finance, 17(1).

Bassey, N. E. Arene, C. J. and Okpukpara, B. C. (2014). Determinants of Capital Structure of Listed Agro Firms in Nigeria. European Journal of Business and Management, 6(27):92-98

Berger, A. N., Herring, R. J. and Szego, G. P. (1995). The Role of Capital in Financial Institutions. Journal of Banking and Finance, 19, 393-430.

Booth, L., Aivazian, V, Demirguc-Kunt, A. and Maksmivoc, V. (2001). Capital structures in developing countries. Journal of Finance, 56, 87-130.

Bradley, M., Jarrell, G. A. and Kim, E. A. (1984). On the existence of an optimal capital structure: theory and evidence. Journal of Finance, 39, 857-878.

Casey, K. M. and Anderson, D. C. (1999). Examining the Impact of the Tax Reform Act on Corporate Dividend Policy: A New Methodology. Journal of Financial Review, 34(3): 17-28.

Chandrasekharan, C. V. (2012). Determinants of capital structure in the Nigerian listed firms. International Journal of Advanced Research in Management and Social Sciences, 1(2).

Chang, E. (1999). Capital Structure: Convergent and Pecking Order Evidence. Review of Financial Economics, 1(1): 35-49.

Chechet, I. L., Garba, S. L., and Odudu, A. S. (2013). Determinants of Capital Structure in the Nigerian Chemical and Paints Sector. International Journal of Humanities and Social Science, 3, 247-263.

Chechet, I. L and Olayiwola, A. B. (2014). Capital Structure and Profitability in Nigerian 
INTERNATIONAL JOURNAL OF ACADEMIC RESEARCH IN BUSINESS AND SOCIAL SCIENCES Vol. 9, No. 5, May, 2019, E-ISSN: 2222-6990 ㄷ 2019 HRMARS

Quoted Firms: The Agency Cost Theory Perspective. American International Journal of Social Science, 3(1).

Chen, L. J. (2009). How the Pecking-Order Theory Explain Capital Structure. (Published

Thesis). Chan Jung Christian University, Taiwan.

Chen, Y. C. and Chen, L. J. (2011). Capital Structure Determinants: An Empirical Study in

Taiwan. African Journal of Business Management, 5(27): 10974-10983.

Collins, R. (2013). The Pecking Order Theory of Capital Structure Choice: The Barbados Experience. (MSc Dissertation). University of Leicester, England.

Dada, F. B. and Ukaegbu, B. (2015). The Pecking Order Theory: Evidence from Listed Firms in Nigeria. International Finance and Banking, 2(2).

Dammon, R. M. and Senbet, L. W. (1988). The Effect of Taxes and Depreciation on Corporate Investment and Financial Leverage. Journal of Finance, 43(2): 357-373.

Diamond, D. W. (1984). Financial Intermediation and Delegated Monitoring. Review of Economic Studies, 51, 447-663.

Drobetz, W. and Fix, R. (2003). What are the determinants of the capital structure? Some evidence for Switzerland. University of Basel. WWZ/ Department of Finance, Working Paper No. 4/03.

Ghazouani, T. (2013). The Capital Structure through the Trade-Off Theory: Evidence from Tunisian Firms. International Journal of Economics and Financial Issues, 5(2):482-488.

Givoy, D., Grossman, S. and Hart, O. (1992) Determinants of Financial Structure: A New Methodological Approach. Journal of Finance 34, 631-644.

Gorton, G. and Winton, A. (1995). Bank Capital Regulation in General Equilibrium. NBER Working Paper, No. 5244.

Grossman, S. and Hart, O. (1982). Corporate financial structure and managerial incentives, in John McCall ed., The Economics of Information and Uncertainty. University of Chicago press, Chicago, IL

Guruswamy, D. and Marew, A. (2016). Determinants of Capital Structure of Selected Insurance Companies in Ethiopia. Developing Country Studies, 6(10).

Harris, M. and Raviv, A. (1990). Capital Structure and the Informational Role of Debt. Journal of Finance, 45, 321-349.

Harris, M. and Raviv, A. (1991). The Theory of Capital Structure. The Journal of Finance, 46 (1): 297-355.

Haugen, R. and Senbet, L. (1978). The Insignificance of Bankruptcy Costs to the Theory of Optimal Capital Structure. Journal of Finance, 33(2): 383-93.

Heaton, J. B. (2002). Managerial Optimism and Corporate Finance. Financial Management, 31, 33-45.

Hoque, J, Hossain, A. and Hossain, K. (2014). Impact of Capital Structure Policy on Value of the Firm- A study on some selected Corporate Manufacturing Firms under Dhaka Stock Exchange. Ecoforum, 3:2(5).

Hovakimian, A. (2006). Are Observed Capital Structures Determined by Equity Market Timing? Journal of Financial and Quantitative Analysis, 41, 221-243.

Huang, S. G. and Song, F. M. (2002): The Determinants of Capital Structure: Evidence from 
INTERNATIONAL JOURNAL OF ACADEMIC RESEARCH IN BUSINESS AND SOCIAL SCIENCES Vol. 9, No. 5, May, 2019, E-ISSN: 2222-6990 ㄷ 2019 HRMARS

China. Hong Kong Institute of Economics and Business Strategy, Working Paper, 2002, No. 1042.

Iwarere, H. T. and Akinleye, G.T. (2010). Capital Structure Determinants in the Nigeria Banking Industry: Financial Managers Perspective. Pakistan Journal of Social Sciences, 7(3): 205-213.

Isola, W. A. and Akanni, L. O. (2015). Corporate Financial Structure in Nonfinancial Quoted Companies in Nigeria. Managing Global Transitions, 13(3): 267-280

Jensen, M. (1986). Agency costs of free cash flow, corporate finance and takeovers. American Economic Review, 76(2): 323-329.

Jensen, M. and Meckling, W. (1976). Theory of the Firm: Managerial Behavior, Agency costs and Ownership Structure. Journal of Financial Economics, 3, 305-360.

Kester, C. W. (1986): Capital and Ownership Structure: A Comparison of United States and Japanese Manufacturing Corporations. Financial Management, 15, 5-16.

Kim, W. S. and Sorensen, E. H. (1986): Evidence on the Impact of the Agency Costs of Debt in Corporate Debt Policy. Journal of Financial and Quantitative Analysis, 21, 131-144.

Kim, J. (1978). Strategy and Financial Policy in UK Small firms. Journal of Business Finance and Accounting, 25(1): 1-27.

Kraus, A. and Litzenberger, R. (1973). A state preference model of optimal financial leverage. The Journal of Finance, 28, 911-921.

Kyereboah-Coleman, A. (2007). The Determinants of Capital Structure of Microfinance Institutions in Ghana. SAJEMS NS, 10(2).

Lev, B. (1969). Industry Averages as Targets for Financial Ratios. Journal of Accounting Research, 290-299.

Lim, T. C. (2012). Determinants of Capital Structure: Empirical Evidence from Financial Services Listed Firms in China. International Journal of Economics and Finance, 4(3).

Masnoon, M., and Saeed, A. (2014). Capital Structure Determinants of KSE Listed Automobile Companies. European Scientific Journal, 10(13).

Matemilola, A. N., Ariffin A. N. and McGowan, C. B. (2012). Trade-Off Theory against Pecking Order Theory of Capital Structure in a Nested Model. Panel GMM Evidence from South Africa. The Global Journal of Finance and Economics, 19(2): 133-147.

Micheal, N. B. (2012). Capital structure determinants of quoted firms in Nigeria and lesson for corporate financing decisions. Journal of Finance and Investment Analysis, 1(2): 61-81.

Mihir, A., Desai, C., Foley, F. and Himes, J. R. (2003). A Multinational Perspective on Capital Structure Choice and Internal Capital Markets. International Investment Division, Bureau of Economic Analysis, US Department of Commerce.

Miller, M. H. (1977). Debt and Taxes. Journal of finance 32, 261-275.

Miller, M. H. (1988). The Modigliani-Miller Propositions. After Thirty Years. Journal of Economic Perspectives, 2 (4): 99-120.

Modigliani, F. and Miller, M. (1958). The Cost of Capital, Corporation Finance, and The Theory of Investment. American Economic Review, 48, 261-297.

Modigliani, F. and Miller, M. (1963). Corporate Income Taxes and Cost of Capital: A Correction. American Economic Review 53, 433-443. 
INTERNATIONAL JOURNAL OF ACADEMIC RESEARCH IN BUSINESS AND SOCIAL SCIENCES Vol. 9, No. 5, May, 2019, E-ISSN: 2222-6990 @ 2019 HRMARS

Modugu, P. A. (2013). Capital Structure Decision: An Overview. Journal of Finance and Bank Management, 1 (1): 14-27.

Muhtar, O. F. and Ahmad, R. (2015). Empirical Evidence of Target Leverage, Adjustment Costs and Adjustment Speed of Non-Financial Firms in Selected African Countries. International Journal of Economics and Financial Issues, 5(2): 482-488.

Mutairi, A. A. and Naser, K. (2015). Determinants of Capital Structure of Banking Sector in GCC: An Empirical Investigation. Asian Economic and Financial Review 5(7): 959-972.

Myers, S. C. (2001). Capital Structure. Journal of Economic Perspectives, 15 (2): 81-102.

Myers, S. C. (1977). Determinants of corporate borrowing. Journal of Financial Economics, $5,147-175$.

Myers, S. C. (1984). The capital structure puzzle. Journal of Finance, 34 (3): 575-592.

Myers, S. C. and Majluf N. (1984). Corporate Financing and Investment Decisions when Firms have Information Investors do not have. Journal of Financial Economics, 13, 187-221.

Neter, J., Kutner, M. H., Nachtsheim, C. J. and Wasserman, W. (1996). Applied Linear Statistical Models. Irwin Company Inc., Chicago, U.S.A.

Nguyen, H. and Kayani, Z. (2013). Determinants of Banks' Capital Structure in Asia- A Comparison Amongst Developed and Developing Countries. (Published MSc Thesis). School of Economics and Management, Department of Business Administration, Lunds University, Sweden.

Nwankwo, O. (2014). Effect of Capital Structure of Nigerian Firms on Economic Growth. Mediterranean Journal of Social Science, 5(1): 515-519.

Ogbulu, O. M. and Emeni, F. K. (2012). Determinants of corporate capital structure in Nigeria. International Journal of Economics and Management Sciences, 1(10): 81-96.

Oke, M. O. and Obalade, A. A. (2015). Testing the Validity of Optimal Capital Structure Theory in Nigerian Listed Oil Firms. International Journal of Economics, Commerce and Management, UK, 3(3).

Olakunle, A. O. and Oni, E. O. (2014). Assessing the Impact of Asset Tangibility on Capital Structure: Choice for Listed Firms in Nigeria. Journal of Applied Economics and Business, 2(3): 5-20.

Olarewaju, O. M. and Akande, J. O. (2016). An Empirical Analysis of Capital Adequacy Determinants in Nigerian Banking Sector. International Journal of Economics and Finance, 8(12): 132-142.

Olokoyo, F. O. (2012). Capital Structure and Corporate Performance of Nigerian Quoted Firms. A Panel Data Approach. Published Ph.D Thesis presented to the Department of Banking and Finance, School of Business, College of Development Studies, Covenant University, Ota, Ogun State Nigeria.

Omorogie, A. N. and Erah, D. O. (2010). An Empirical Investigation of Capital Structure and Corporate Performance in Nigeria. Journal of Management Sciences, 1(1): 43-52.

Onaolapo, A. A., Kajola, S. O., and Nwalobie, M. B. (2015). Determinants of capital structure: A study of Nigerian quoted companies. European Journal of Business and Management, 7(23). Oolderink, P, (2013). Determinants of Capital Structure: Static Trade-Off Theory Vs 
INTERNATIONAL JOURNAL OF ACADEMIC RESEARCH IN BUSINESS AND SOCIAL SCIENCES Vol. 9, No. 5, May, 2019, E-ISSN: 2222-6990 ㄷ 2019 HRMARS

Pecking-Order Theory. Evidence from Dutch Listed Firms. (Published Thesis). University of Twente, The Netherlands.

Otaru, O. (2017). List of Insurance Companies quoted on the Nigeria Stock Exchange. Naijabizcom.com

Patrick, O., Joseph, O. and Kemi, A. (2013). The impact of capital structure on firms' performance in Nigeria. Munich Personal REPEC Archive (MPRA), 1-24.

Pettit, R. and Singer, R. (1985). Small Business Finance: A Research Agenda. Financial Management, 14(3): 47-60.

Prasad, S., Green, C., and Murinde, V. (2003). Company Financial Structures in Developing Economies: Evidence from a Comparative Analysis of Thai and Malay Companies. Working Paper, University of Birmingham.

Rajan, R. G. and Zingales, L. (1995). What do we know about Capital Structure? Some evidence from international data. Journal of Finance, 50(5): 1421-1460.

Ross, S. A. (1977). The Determination of financial structure: the incentive signaling approach. Bell Journal of Economics, 23-40.

Salawu, R. O. (2007). An Empirical Analysis of the Capital Structure of Selected Quoted Companies in Nigeria. International Journal of Applied Economics and Finance, 1(1): 16-28.

Salawu, R. O. and Agboola, A. A. (2008). The Determinants of Capital Structure of Large Non-Financial Listed Firms in Nigeria. The International Journal of Business and Financial Research, 2(2).

Saleem, F., Rafique B., Mehmood, Q., Irfan, M., Saleem, R., Tariq, S., and Akram, G. (2013). The Determination Of Capital Structure of Oil and Gas Firms Listed on Karachi Stock Exchange in Pakistan. Interdisciplinary Journal of Contemporary Research in Business, 4(9).

Santos, J. A. C. (1999). Bank Capital Regulation: A Review of the Theoretical Literature. BIS Working Paper.

Santos, J. B. and Britto L. A. L (2012). Toward a Subjective Measurement Model for Firm Performance. Brazillian Administrative Review, 9(6): 95-117

Shala, A., Ahmeti, S., Berisha, V., and Perjuci E. (2014). The Factors that Determine the Capital Structure among Insurance Companies in Kosovo: Empirical Analysis. Academic Journal of Interdisciplinary Studies, 1(2).

Shehu, U. H. (2011). Determinants of Capital Structure in the Nigerian Listed Insurance Firms. International Journal of China - USA Business Review, 10(12): 81-98.

Shehu, U. H. and Joseph, A. (2017). Capital Structure and Investment Growth Opportunity of Listed Pharmaceutical Firms in Nigeria. Asian Business Research, 2(1).

Shrieves, R. E. and Dahl, D. (1992). The Relationship between Risk and Capital in Commercial Banks. Journal of Banking and Finance, 16, 439-457.

Stiglitz, J. (1974). On the Irrelevance of Corporate Financial Policy. The American Economic Review, 64(6): 851-866.

Stultz, R. (1990). Managerial discretion and optimal financing policies. Journal of Financial Economics, 26, 3-27.

Supa, T. (2012). Key Factors Influencing Capital Structure Decision and Capital Structure 
INTERNATIONAL JOURNAL OF ACADEMIC RESEARCH IN BUSINESS AND SOCIAL SCIENCES Vol. 9, No. 5, May, 2019, E-ISSN: 2222-6990 @ 2019 HRMARS

Dynamics: Evidence from Listed companies in SET. (Published PhD Thesis). Rajamangala University of Technology, Thanyaburi, Thailand.

Suto, M. (2003). Capital structure and investment behaviour of Malaysian firms in the 1990s:

A study of corporate governance before the crisis. Corporate Governance, 11, 25-39.

Titman, S. (1984). The effect of capital structure on the firm's liquidation decision. Journal of Financial Economics, 13, 137-151.

Titman, S. and Wessels, R. (1988). The determinants of Capital Structure Choice. The Journal of Finance, 43 (1): 1-19.

Tobachnick, B.G. and Fidell, L.S. (1996). Using Multivariate Statistics, (3rd Edition), HarperCollins, New York, U.S.A.

Tonye, C. and Andabai, P. W. (2015). Determinants of Capital Structure and Firm's Performance in Nigeria (1989-2014): An Empirical Investigation Approach. International Journal of Management and Economics Invention, 1(10): 471-479.

Ubesie, M. C. and Nwankwojike, C. A. (2012). Determinant of Capital Mix in Developing Economies; Evidence from Nigeria Breweries Sector. Agricultural Economics and Journal, 5(2): 7-10

Vitor, D. A. and Badu, J. (2012). Capital Structure and Performance of Listed Banks in Ghana. Global Journal of Human Social Science, 12(5).

Voulgaris, F, Asteriou, D. and Agiomirgianakis, G. (2004). Size and Determinants of Capital Structure in the Greek Manufacturing Sector. International Review of Applied Economics, 8 (2).

Warner, J. B. (1977). Bankruptcy Costs: Some Evidence. The Journal of Finance, 32(2): 3747.

Wiwattanakantang, Y. (1999). An empirical study on the determinants of capital structure of Thai. Pacific-Basin Finance Journal, 7, 371-403.

Xhaferi, S. and Xhaferi, B. (2015). Alternative Theories of Capital Structure. European Journal Scientific Journal, 11(7): 327-343.

Zurigat, Z. (2009). Pecking-Order Theory, Trade-Off Theory and Determinants of Capital Structure: Empirical Evidence from Jordan. (Published Ph.D Thesis). Heriot-Watt University, Scotland. 